\title{
O FLORAM em discussão
}

\section{LUIZ G. E. BARRICHELO}

$\mathbf{E}$

laborado no IEA para ser discutido por todos os interessados e oferecido à sociedade brasileira, $o$ Projeto FLORAM náo pode em nenhuma hipótese ser confundido com uma alternativa à política florestal do País, podendo, todavia, ser incorporado por ela. Aliás, desde sua concepçáo, nunca foi qualificado ou apresentado dessa maneira. Pode ser uma oportunidade ímpar para uma nova visáo da realidade florestal brasileira. Por outro lado, ousa apresentar para discussáo um elenco de açōes concretas e variáveis para a superaçáo da fase analítica e contemplativa em que essa mesma realidade florestal está mergulhada há muitos anos.

O grande mérito do FLORAM é assentar-se em diretrizes ecológicas, sociais e econômicas. Nele, é fundamental que sejam alcançados resultados equivalentes e simultâneos nessas três áreas em todas as fases de seu desenvolvimento. Para isso, é preciso haver a concordância de que é possivel compatibilizar a preservação do meio ambiente, suas florestas nativas, recuperação de áreas de interesse ecológico e paisagístico e a silvicultura intensiva que visa a produçáo de biomassa para energia e de madeira para abastecimento industrial.

Decorrência da "síndrome de incentivos fiscais" (quando são analisados somente os malefícios destes), ocorre para alguns um misto de surpresa quando o projeto propóe uma área de 20 milhões de hectares (2,3\% do território brasileiro) a serem reflorestados num prazo de $\mathbf{2 0}$ - $\mathbf{3 0}$ anos. Para muitos, algo de tal magnitude traz à mente mirabolantes extensóes de monoculturas, êxodo rural, desalojamento da agricultura, concentração de terras, eliminação da fauna, prejuízos irreparáveis à biodiversidade, "esterilizaçăo" do solo, desertos ... o caos!

Năo restam dúvidas de que cabe separar, primeiro, o que existe de lenda e realidade; no primeiro caso, é preciso estabelecer os fatos à luz 
dos conhecimentos atuais; no segundo, lançar măo de todas as medidas existentes para eliminar ou minimizar os possíveis prejuízos e desvios que possam ocorrer. Nos dias atuais, a própria sociedade brasileira já evoluiu o suficiente para exercer um poder de pressáo e controle através de seus líderes políticos e grupos ambientalistas.

O grupo de trabalho que coordena o FLORAM preconiza que todos esses pontos sejam discutidos e esclarecidos, e que as devidas e necessárias medidas preventivas e corretivas sejam sugeridas.

Por outro lado, o projeto deve realmente ser, na sua somatória, um megareflorestamento, pois sua proposta essencial não é o retorno ao "Brasil do milagre", nem atender ao abastecimento industrial. $O$ FLORAM é mais oúsado: "pretende ser uma iniciativa brasileira destinada a iniciar um movimento internacional para a fixação do excesso de 115 bilhões de toneladas de carbono em suspensão na atmosfera", conforme já definido nos documentos editados pelo IEA. Dentro dessa ótica, a mensagem já ultrapassou nossas fronteiras.

A ciência e a tecnologia brasileira, na área e abrangência do projeto, estáo suficientemente aparelhadas para enfrentar esse desafio com os conhecimentos acumulados nas universidades, institutos e centros de pesquisas junto à iniciativa privada. Só dependem de uma decisão política para concentrar os esforços de forma coordenada e construtiva e, o que é mais importante, sem preconceitos ou traumas do passado.

$\mathrm{Na}$ atualidade, o Brasil é reconhecido internacionalmente pela tecnologia desenvolvida na formaçáo de florestas de rápido crescimento. Além disso, o País vem concentrando sua atençáo nos conhecimentos sobre manejo de florestas tropicais, agrossilvicultura, recuperação de áreas degradadas e matas ciliares.

O projeto entra numa fase decisiva, na qual suas propostas sảo colocadas para discussáo pelos diferentes segmentos da comunidade científica, política e econômica. Apoiada num debate amplo, a sociedade deve assimilá-lo, havendo a expectativa de que os órgáos governamentais e a iniciativa privada o administrem dentro da realidade ecológica/social/econômica citada. Nesse momento, estará cumprida a missão do IEA e do grupo coordenador do FLORAM. 